\title{
Mobilidade territorial e política no discurso de lideranças indígenas do/no estado do Acre (Amazônia, Brasil)
}

\section{Territorial and political mobility in the speech of indigenous leaders of/in the State of Acre (Amazonia, Brasil)}

\section{Movilidad territorial y política en el discurso de los líderes indígenas del/en el Estado de Acre (Amazonia, Brasil)}

Alessandra Severino da Silva Manchinery Indígena do povo Manchineri

https:/ / orcid.org/0000-0003-0808-7748

amanchinery@gmail.com

Universidade Federal de Rondônia, UNIR, Porto Velho, RO

Suzanna Dourado da Silva https:/ / orcid.org/0000-0002-3084-9529 suzannadourado@gmail.com Universidad Nacional Autónoma de México, UNAM, Ciudad de México, México

Adnilson de Almeida Silva https:/ / orcid.org/0000-0003-2555-0861

adnilson@unir.br

Universidade Federal de Rondônia, UNIR, Porto Velho, RO

Resumo: Propõe-se discutir a mobilidade territorial, as políticas de lideranças indígenas no estado do Acre, especialmente os Manchineri, e suas estratégias de sobrevivência no mundo do não-indígena, de modo que se possa refletir sobre duas mudanças que testemunhamos nas últimas décadas: a mobilidade para os centros urbanos, que inclui os indígenas nascidos na cidade e os que para ela se deslocaram, bem como a sua crescente adesão às discussões políticas indígenas e indigenistas do país. $\mathrm{O}$ caminho metodológico teve como partida a própria ótica das lideranças, para isso será relatado seu modo vida e seus envolvimentos nas políticas de distintas esferas de decisão. $\mathrm{O}$ artigo é composto por três seções de discussão que vão da mobilidade ao papel político desempenhado pelas lideranças indígenas.

Palavras chaves: estratégias e protagonismos, povos originários, política indigenista.

Abstract: It is proposed to discuss territorial mobility, the policies of indigenous leaders in the state of Acre, especially the Manchineri, their survival strategies in the world of non-indigenous people so that we can reflect on two changes that we testify in recent decades: mobility for the urban centers that include the indigenous people who 
were born in the city and those who arrived in the city, as well as its growing support in the country's indigenous and non-indigenous political discussions in Brazil. The methodological path had as its own perspective of the leaders, for this will be reported their way of life and their involvement in the policies of different spheres of decision. The paper consists of three discussion sections that go from mobility to the political role played by leaders.

Keywords: strategies and protagonisms, indigenous peoples, indigenous policies.

Resumen: Se propone discutir la movilidad territorial, las políticas de los líderes indígenas en el estado de Acre, especialmente los Manchineri, sus estrategias de supervivencia en el mundo de los no indígenas, para que podamos reflexionar sobre dos cambios que hemos presenciado en las últimas décadas: la movilidad para los centros urbanos que incluyen a los indígenas que nacieron en la ciudad y los que llegaron a la ciudad, así como su creciente adhesión a las discusiones políticas indígenas y no indígenas en Brasil. El camino metodológico partió desde la propia perspectiva de los líderes, para ellos se dará cuenta de su forma de vida y su implicación en las políticas de los diferentes ámbitos de decisión. El artículo es compuesto con tres secciones de discusión que van desde la movilidad hasta el papel político realizado por los líderes indígenas.

Palabras clave: estrategias y protagonismos, pueblos indígenas, políticas indigenistas.

\section{CONSIDERAÇÕES INICIAIS}

O artigo foi construído a partir da perspectiva da primeira autora, a qual apresenta sua experiência como indígena do povo Manchineri e sua participação efetiva na construção-debates e ações que envolvem indígenas também categorizados como "povos originários", em escala local, regional, nacional e internacional, além de pertencer ainda ao campo da ciência geográfica. Com tais qualificações, é relevante destacar que seu enraizamento se alicerça nas falas das lideranças que participam de encontros e reuniões na cidade de Rio Branco (Acre) e em Brasília (DF), pelas quais sempre esteve presente como jovem, mulher e componente voluntária da organização indígena Manxinerune Tsihi Pukte Hajene - MATPHA ${ }^{1}$.

No entanto, discutir e analisar a mobilidade territorial ${ }^{2}$ de povos indígenas tem sido um trabalho árduo, pois estudos com essa temática são escassos nas áreas humanas, sobretudo nas abordagens e temas geográficos, o que afeta em grande contexto esboços sobre os povos originários, e efetiva-se um problema colonial de ocultamento da visibilidade indígena.

Neste caso, é importante ressaltar que a Geografia enquanto ciência pode ser a ponte e o instrumento que possibilite a voz desses povos, que ao longo da trajetória histórica

1 Em português corresponde à Organização Manchineri de Moradores das Grandes Aldeias.

2 A mobilidade aqui retratada não se refere aos tempos antes do contato quando as terras e territórios não eram demarcadas oficialmente pelo Estado. Em várias obras, especialmente da Antropologia, que tratam das perambulações, as quais são consideradas como outros modos de mobilidades (com enfoque cultural) para que pudessem caçar, pescar, estabelecerem relações de matrimônios, promoverem guerras entre etnias na disputa por territórios. 
nacional tiveram seus direitos negados e usurpados, particularmente no que se refere à terra e à garantia da integridade física, cultural e espiritual.

Mediante a essas questões, as políticas de lideranças indígenas no estado do Acre nos levaram a compreender suas estratégias de sobrevivência na sociedade envolvente nacional. Mas para perceber como encontram-se as políticas indígenas, a primeira autoria teve que se colocar como participante efetiva nas discussões sobre as questões e diretrizes para as coletividades dos povos originários. Assim, parte-se de sua vivência e percepção sobre duas importantes mudanças ocorridas nas últimas décadas, as quais se refletem: a) a mobilidade acelerada de povos originários brasileiros para os pequenos, médios e grandes centros urbanos, especialmente na Amazônia; b) a crescente adesão de caciques e lideranças indígenas nas discussões políticas e indigenistas que ocorrem no Brasil.

Deste modo, defende-se que a permanência de indígenas em espaços governamentais e não governamentais é necessária e relevante, tão-somente, pode se consolidar o duplo pertencimento ${ }^{3}$ de ser indígena na/da cidade; esta é uma compreensão de afirmar que existe o indígena $d a$ cidade $^{4}$ que são aqueles que nasceram no meio urbano; já o na cidade ${ }^{5}$ é aquele que chegou através da mobilidade "forçada". Essa construção se opera de modo duro e em permanente estado assimétrico, devido a tantos problemas existentes dentro das aldeias como falta de assistência à saúde e educação, como também a falta de apoio governamental. Neste caso, torna-se visível que com ajuda familiar as lideranças efetivam a mobilidade com expectativa de ajudar a comunidade de origem.

O sentido de duplo pertencimento que existe o indígena da cidade e o na cidade apresenta complexidade, a qual está intrinsecamente vinculado ao território, conforme consideram Bonnemaison e Cambrèzy (1996, p.13-14) apud Almeida Silva (2010, p.223):

Pertencemos a um território, não o possuímos, guardamo-lo, habitamo-lo, impregnamo-nos dele. Além disso, os viventes não são os únicos a ocupar o território, a presença dos mortos marca-o mais do que nunca com o signo do sagrado. Enfim, o território não diz respeito apenas à função ou ao ter, mas ao ser. Esquecer este princípio espiritual e não material é se sujeitar a não compreender a violência trágica de muitas lutas e conflitos que afetam o mundo de hoje: perder seu território é desaparecer. (Tradução e Grifos nossos).

Tal constatação repercute diretamente no processo, no qual começa a saga que representa a contemporaneidade na história dos povos originários brasileiros, mas especificamente no Acre, pela qual é marcada pelas constantes ofensivas e intencionalidades com o desígnio e tentativas de se colocar em prática a subalternidade e o assimilacionismo promovidos pelo Estado nacional, por outro lado se constata a capacidade protagonista de interação e resistência política e cultural desses diferentes povos frente a novos desafios.

3 O fato de o indígena ter nascido na cidade ou ter se mudado para ela, permite que tenha vivência entre mundos de culturas e valores distintos. Assim, não deixa de ser indígena e ao mesmo tempo, urbano.

4 Destacamos que pelas condições impostas pela dinâmica da cidade, os povos indígenas que nela moram encontram-se vulneráveis, vez que a maioria está em condições precárias de habitações em bairros periféricos, sem infraestrutura, além do fato de discriminação étnico-racial.

5 Para além disso tem-se ainda aqueles que procuram a cidade, mas que não moram nela, para obterem apoio e estabelecerem parcerias para que possibilitem garantir-lhes o direito, inclusive no que se refere ao usufruto de seus territórios originários. 
Um desses desafios dos povos indígenas diz respeito ao direito à terra, à moradia, à reprodução social e cultural, ainda que se operacionalize na cidade. Concordamos com a geógrafa Ivani Faria (2003, p.125) ao discorrer sobre o conceito de território, visto que este é uma "evolução do conceito de terra que adquiriu os sentidos de limite e de planejamento, porém as representações cosmológicas inerentes à cultura indígena, que não contém a percepção ocidental de território [...]. Terra é considerada como mercadoria, contendo valor de troca". Destarte, o sentido e a importância do território para o indígena têm relação na representação da sobrevivência do coletivo, no qual imprime sua cultura e modo de vida.

No nosso entendimento a mobilidade só pode ocorrer em função da existência do território. Como resultado dos processos da mobilidade, muitas vezes compulsória, houve a efetivação política e progressivamente de uma série de conquistas, particularmente, nas duas últimas décadas pelos povos originários brasileiros; neste âmbito o discurso político de suas lideranças tem-se protagonizado - ainda que muito recentemente, em pautas reivindicatórias do movimento indígena em nível nacional e internacional.

A política indígena neste caso, é um exemplo da potencial luta pela terra ancestral, bem como a socialização do conhecimento tradicional-social-cultural e da garantia constitucional de livre circulação em âmbitos territoriais; por outro lado o desencontro de informações, faz com que parcela da sociedade abrangente considere que os indígenas e suas terras tem se constituído alvo de retrocessos para o desenvolvimento do país, ao mesmo tempo em que ocorrem ausências do Estado nacional no cumprimento dos direitos das populações originárias.

Em conformidade com as informações do site da Comissão Pró-Índio do Acre (CPI/ AC), acessado em 10 de setembro de 2020, existem 35 Terras Indígenas (TIs), que totalizam $14,6 \%$ do estado ${ }^{6}$, com uma população estimada em 23 mil indígenas ${ }^{7}$ de 15 povos pertencentes às famílias Pano, Aruak e Arawá, bem como os categorizados como isolados, sem identificação, e um coletivo de recém-contato.

A Figura 1 demonstra a localização das TIs no Acre, onde várias encontram-se sobrepostas por Unidades de Conservação, inclusive de Reservas Extrativistas (cujas conquistas de territórios são decorrentes de intensas lutas e reivindicações assim como ocorrido com as TIs, sendo que também sofrem pressões, ameaças constantes, além das ausências de atuação do poder público).

Mediante as dificuldades encontradas nas TIs, que serão explicitadas ao longo do artigo, os indígenas lutaram e lutam pelo direito permanente a um lugar como moradia nos centros urbanos que possa garantir acesso às informações e ações das políticas de governo para assim se prevenirem contra ataques genocidas a que esses povos são sujeitos históricos e epistêmicos.

6 Departamento de Áreas Protegidas e Biodiversidade/Secretaria de Estado de Meio Ambiente do (SEMA-AC).

7 CPI-Acre, 2018; AMAAI-AC, 2018; FUNAI; SEMA-AC; SESAI, 2013. 
Figura 1: Localização das Terras Indígenas no estado do Acre.

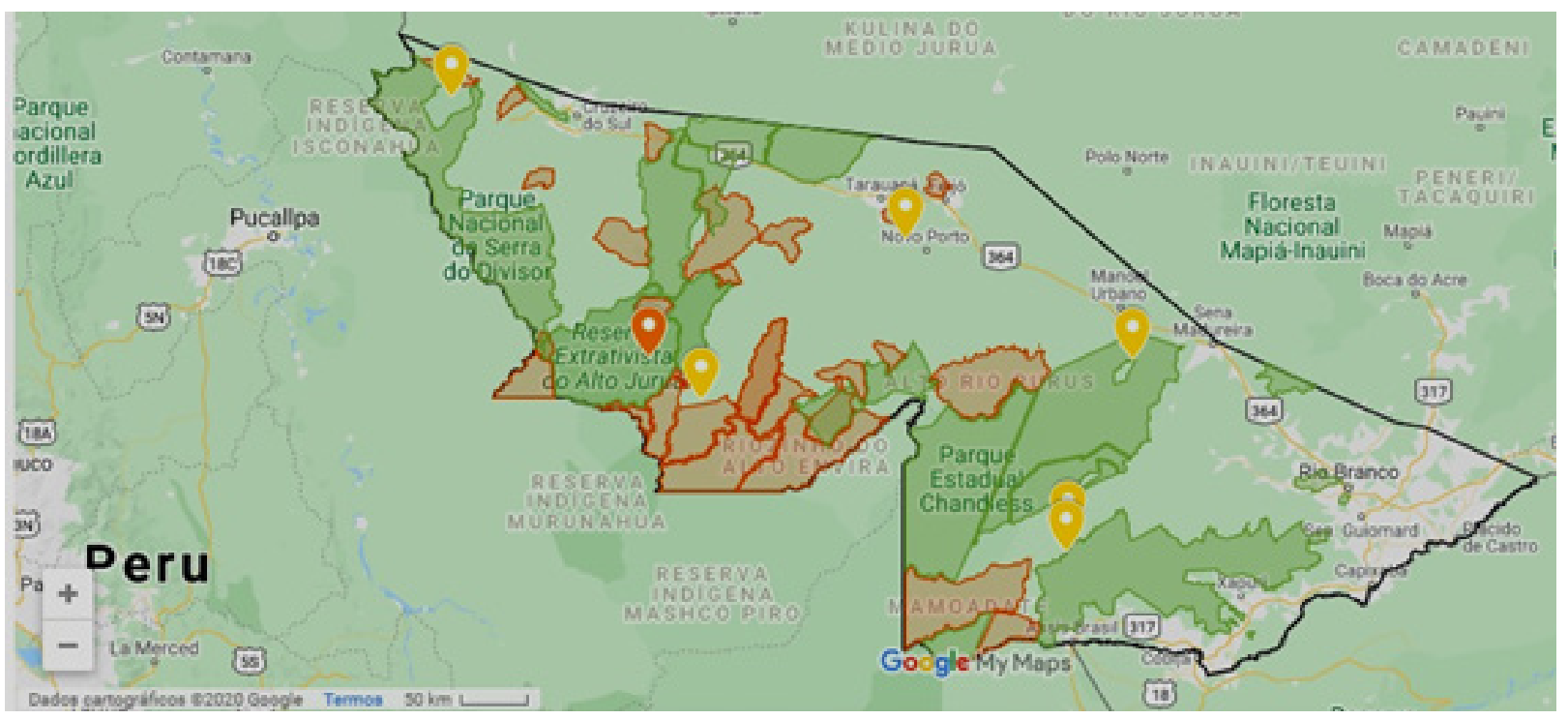

Fonte: Dados cartográficos Google (2020). Disponível em: http:/ /cpiacre.org.br/terras-indigenas-no-acre/.

Daí decorre a motivação para redigirmos e apresentarmos o trabalho com as concepções e óticas indígenas, que ainda são vistos por parcela significativa da sociedade envolvente e/ou abrangente como incapazes, logo, subalternos e sem autonomia ou ainda como obstáculos ao processo de desenvolvimento.

Compreendemos que tais visões comportam vivências e modos distintos de apreensão de mundo, de modo que concordamos com a afirmação de Spivak (2010, p.14) que "as camadas mais baixas da sociedade constituídas pelos modos específicos de exclusão dos mercados, da representação política e legal, e da possibilidade de se tornarem membros plenos no estrato social dominante" produzem suas próprias representações e discursos representativos, os quais os situam como agentes de suas manifestações culturais populares como uma fidedigna voz subalterna, representativa de sua realidade de vida enquanto sujeitos.

Neste sentido, é que se insere em nosso trabalho duas modalidades de territorialidades urbanas de indígenas: os que se encontram urbanizados e os que estão na cidade. Os primeiros são os que absorveram os códigos, significados e sentidos da vida citadina; já o outro grupo se refere às pessoas que moram ou circulam pela cidade, todavia, sustentam seu pertencimento cultural vinculado à sua aldeia ou TI. No nosso caso, o foco é buscar compreender o protagonismo das lideranças indígenas na cidade com suas estratégias políticas em um ambiente adverso da floresta.

\section{ABORDAGENS E PERCURSOS METODOLÓGICOS}

O artigo foi construído a partir da interlocução dialógica com as lideranças indígenas do Acre, com as quais temos relações de vivências, olhares e envolvimentos políticos em âmbito local, nacional e internacional. A primeira autora é indígena, integra movimentos 
de povos originários, portanto o trabalho se insere no campo da pesquisa-participante, a qual se fundamenta na construção do conhecimento resultante da compreensão, da ação e da transformação de determinada realidade, onde cada pessoa constitui uma fonte original, insubstituível e inestimável de saber (Brandão, 1981). Assim, o nosso nível de abordagem parte das concepções de mundo dos Manchineri e de sua relação de externalidade. Não se trata de uma pesquisa de fora para dentro (do olhar do 'estranho'), mas de uma ótica construída pela trajetória e modo de vida, em que a vivência e a experiência são intrínsecas ao viver desse povo originário.

Neste sentido, refletem-se vivências e experiências adquiridas que ultrapassam a visão dicotômica entre sujeito/objeto, pesquisador/pesquisado, numa construção de saberes que, ao longo da trajetória de seu povo, tem proporcionado ações transformadoras dentro e fora das suas territorialidades. Assim, a exposição desses percursos procura mostrar a atualidade e preencher algumas lacunas ainda não detalhadas pela Geografia e desconhecidas da sociedade envolvente e/ou abrangente.

Para além das vivências e experiências, a base de construção de construção do artigo se ancorou nos relatos orais e entrevistas com as lideranças indígenas Manchineri que detalharam suas trajetórias no processo de mobilidade territorial, bem como executam a política e edificam discurso que possam garantir ao seu povo a conquista de direitos.

Para Oliveira (2016, p.91) "Cada rio canta uma história, cada curva nos mostra uma nova geografia". No artigo procuramos a visão dos povos originários, uma vez que cada ser humano tem a sua própria história, a da vida e da experiência, o que possibilita não apenas compreender sua relevância enquanto povo, como compartilhar outros saberes que interessam ao campo de análise da Geografia.

Estruturalmente a proposta compõe-se de três seções que contribuem na análise da questão central da mobilidade e a política empreendida, especialmente, pelos Manchineri, a saber: 1) Mobilidade e trajetórias de líderes indígenas; 2) Lideranças indígenas na cidade e seus relatos de vida e estratégias de sobrevivência no meio urbano; 3) Lideranças políticas indígenas e indigenistas - com breve abordagem sobre suas inserções no contexto político e social.

\section{MOBILIDADE E TRAJETÓRIAS DE LÍDERES INDÍGENAS}

A mobilidade de povos indígenas tem sido crescente nos últimos anos, e aqui demonstramos o papel exercido por suas lideranças a partir de suas experiências de vidas e de lutas. Ressaltamos também que seus discursos apresentam óticas próprias, ou seja, diferentes olhares, percepções e apreensões de mundo, em virtude que cada povo se encontra em temporalidade e territorialidade/espacialidade distintas.

A primeira declaração sobre a motivação real dos líderes saírem de suas aldeias e se mudarem para as cidades foi exposta por E.S.S.M. em entrevista na cidade de Rio Branco, em 2017. Residente nesta cidade desde 1979, ele assim se apresentou: "Sou E.S.S.M. e nasci em 8 de junho de 1968, no seringal Petrópolis. Sou conhecido como T. por meu povo, os 
Manchineri, da família linguística Aruak. Meu pai se chama Zé U., em português, J.S.S.M., ex-cacique da comunidade Manchineri da Aldeia Extrema, Rio Iaco ou Kajpaha como é conhecida por meu povo. Minha mãe, já falecida, chamava-se M.S.S. Em vida, ela era o esteio de nossa família, e toda educação que tenho hoje veio dela e de minha avó por parte de pai, que se chamava P. Maimará. Meu pai viajava muito a trabalho, juntamente com seus primos, sobrinhos e tios, a serviço do dono seringal Petrópolis. Quando em vida, minha mãe e minha avó gostavam de criar pequenos animais, como galinha, pato, carneiro e suínos, e isso garantia nossa alimentação quando meu pai estava em viagem. Tenho 49 anos, sou pai de sete filhos, sendo quatro mulheres e três homens, também sou avô. Atualmente, faço consultoria pontuais, e a convite de T.M. Taurepang vou assessorar a União das Mulheres Indígenas da Amazônia Brasileira - UMIAB, e represento a Articulação dos Povos Indígenas do Brasil - APIB na Comissão Nacional para Redução das Emissões de Gases de Efeito Estufa Proveniente do Desmatamento e da Degradação Florestal, Conservação dos Estoques de Carbono Florestal - CONAREDD+. No ano de 1979, fui enviado por meu pai e minha mãe a estudar na cidade de Rio Branco, no Estado do Acre. Na cidade, tive oportunidade de conhecer R. Apurinã, A. Apurinã, B. Yawanawa, Z. Kaxarari, F.A. Apurinã, S. Yawanawa, R. Apurinãe R. Yawanawa - todos com os mesmos objetivos de estudar. Na cidade de Rio Branco, fundamos a Associação dos Estudantes Indígenas do Acre e Sul do Amazonas. Nosso papel principal foi auxiliar as lideranças indígenas do Acre, sul do Amazonas e noroeste de Rondônia a marcar as audiências com as autoridades não indígenas, ou seja, fazer uma assessoria às lideranças".

Como se constata na declaração de E.S.S.M. sobre o movimento indígena, inclusive como Coordenador de Área, Território e Recursos Naturais, representante indígena da Amazônia brasileira dentro da $\mathrm{COICA}^{8}$, a motivação da saída de sua comunidade ocorreu devido à necessidade de se adquirir conhecimentos do não-indígena ${ }^{9}$, já que até aquele momento morava na aldeia, e em razão das inúmeras dificuldades as escolas indígenas ${ }^{10}$, como persiste até os dias atuais, só tinha acesso até as primeiras séries iniciais do ensino fundamental (o antigo primário). Essa necessidade fez com que seu pai o enviasse para a cidade, em busca de uma formação que lhe garantisse autonomia na luta por direitos de seu povo.

Frente às situações apresentadas, os Manchineri encontram-se dispersos nas TIs Mamoadate, Seringal Guanabara, no São Francisco e no Macauã, bem como nas áreas urbanas de Assis Brasil, Brasiléia, Epitaciolândia, Rio Branco, Sena Madureira e Xapuri (Fig. 2).

8 Coordinadora de las Organizaciones Indígenas de la Cuenca Amazônica (Coordenadoria das Organizações Indígenas da Bacia Amazônica).

9 Esses conhecimentos são estruturados a partir da lógica e percepção da sociedade envolvente e/ou abrangente, no caso da educação formal com as escolas urbanas e rurais, as quais que não tratam as especificidades e realidades da cosmovisão indígena; na educação informal pela vivência e verdades do senso comum.

10 Com muitas lutas e reivindicações junto ao poder público, vários dos povos indígenas conquistaram a construção de escolas, além da contratação de professores indígenas. O ensino formal nas aldeias em geral é efetuado por professores não-indígenas e indígenas (professores e sabedores). Algumas das escolas possuem arquitetura baseada nas culturas dos povos originários. Em relação a materiais didáticos na língua materna, sua elaboração é um grande desafio e são raros os estabelecimentos de ensino nas aldeias que contam com esses instrumentos necessários ao ensino e aprendizagem. Assim, pode-se dizer que existem dois processos: a) a educação formal não indígena presente nas aldeias, que necessita da escola; b) a educação indígena que é realizada no cotidiano desses povos, como em atividades de caça, pesca, roçado, floresta, rituais, dentre outros que contribuem na formação humana, cultural, social e espiritual dos indígenas. 
Figura 2: Espacialização do povo indígena Manchineri no estado do Acre.

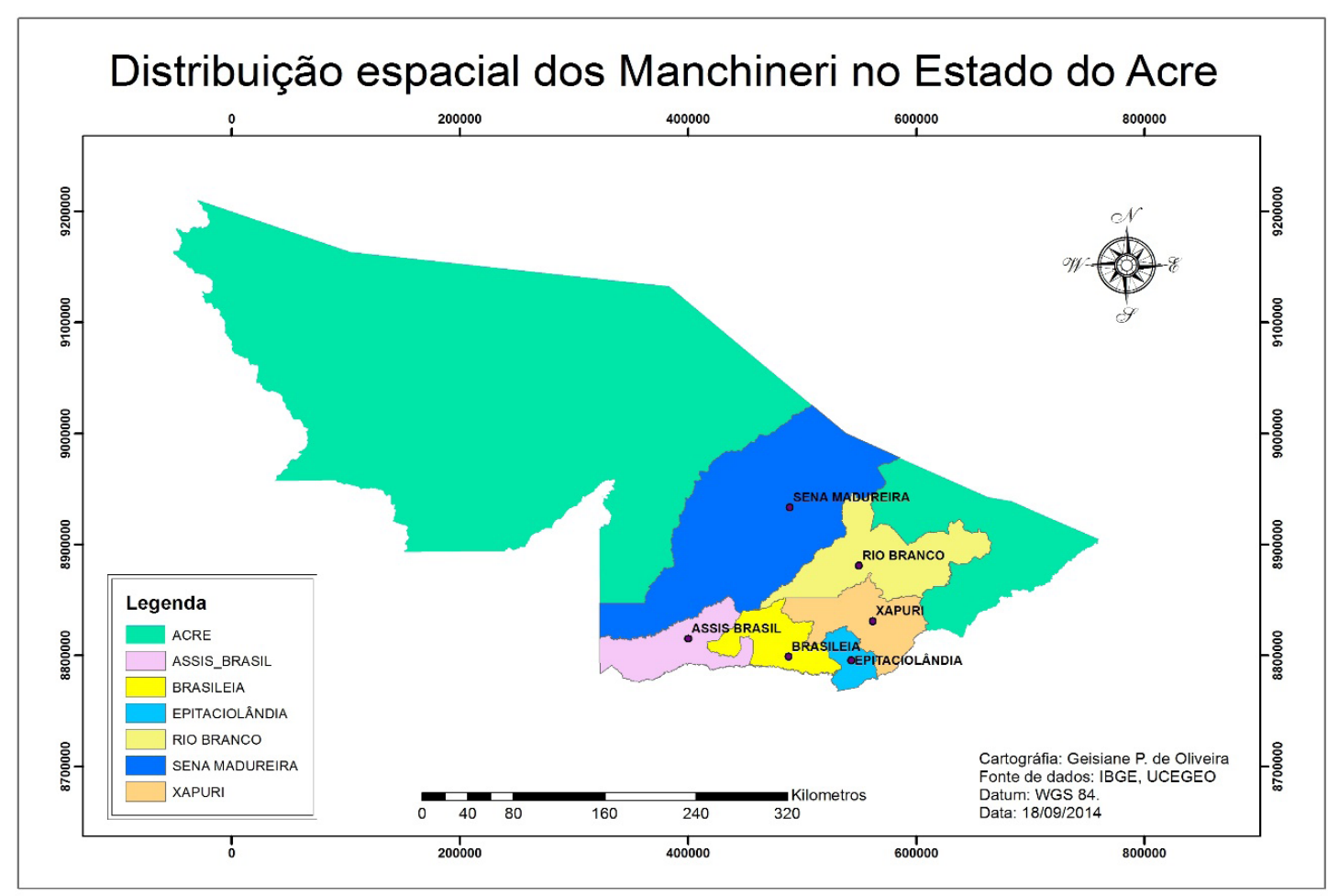

Fonte: Base de dados do IBGE, UCEGEO.

Os Manchineri abrigam em suas TIs povos de outras etnias originárias, concomitantemente integram à família linguística seus parentes Piro (Peru) e Yine (Bolívia), ou seja, constituem-se de um povo que compõem a mesma identidade de pertencimento em três distintos países, o que totaliza aproximadamente 1.400 pessoas, de acordo com o Instituto Socioambiental (ISA) ${ }^{11}$ e 833 conforme Manchinery $\left(2014\right.$, p.30) ${ }^{12}$.

Durante anos de intensa luta para conquistar a garantia de seus direitos, os indígenas têm apreendido novos códigos de sobrevivência, significados e sentidos para sobreviver no meio urbano, e concomitantemente se envolvem politicamente para contribuir com as demandas de suas etnias. Assim, como E.S.S.M, a grande maioria dos membros de sua família fixou residência em Rio Branco; os dados do Conselho Indigenista Missionário (CIMI, 2012), apontam que que aproximadamente de 1.020 indígenas $^{13}$ de 16 povos fixaram residência na capital do Acre (Fig. 3).

11 Disponível em: https://pib.socioambiental.org/pt/Quadro_Geral_dos_Povos.

12 O total refere-se aos Manchineri que moram nas TIs Mamoadate (homologada) e Seringal Guanabara (em processo de identificação) e da área privada Onça Pintada (localizada em Xapuri). No lado peruano e boliviano também vivem Manchineri em duas TIs e nas cidades de Inãpari e San Pedro de Bolpebra. Assim, sua população está distribuída em 12 aldeias, nas quais quatro delas abrigam 267 indígenas Jaminawa (p.30).

13 Esses dados, ainda que com um lapso considerável de tempo, são os últimos disponibilizados. Decorridos oito anos, estimamos que a população indígena em Rio Branco esteja próxima a 2.000 pessoas. 
Figura 3: Povos indígenas residentes em Rio Branco, Acre.

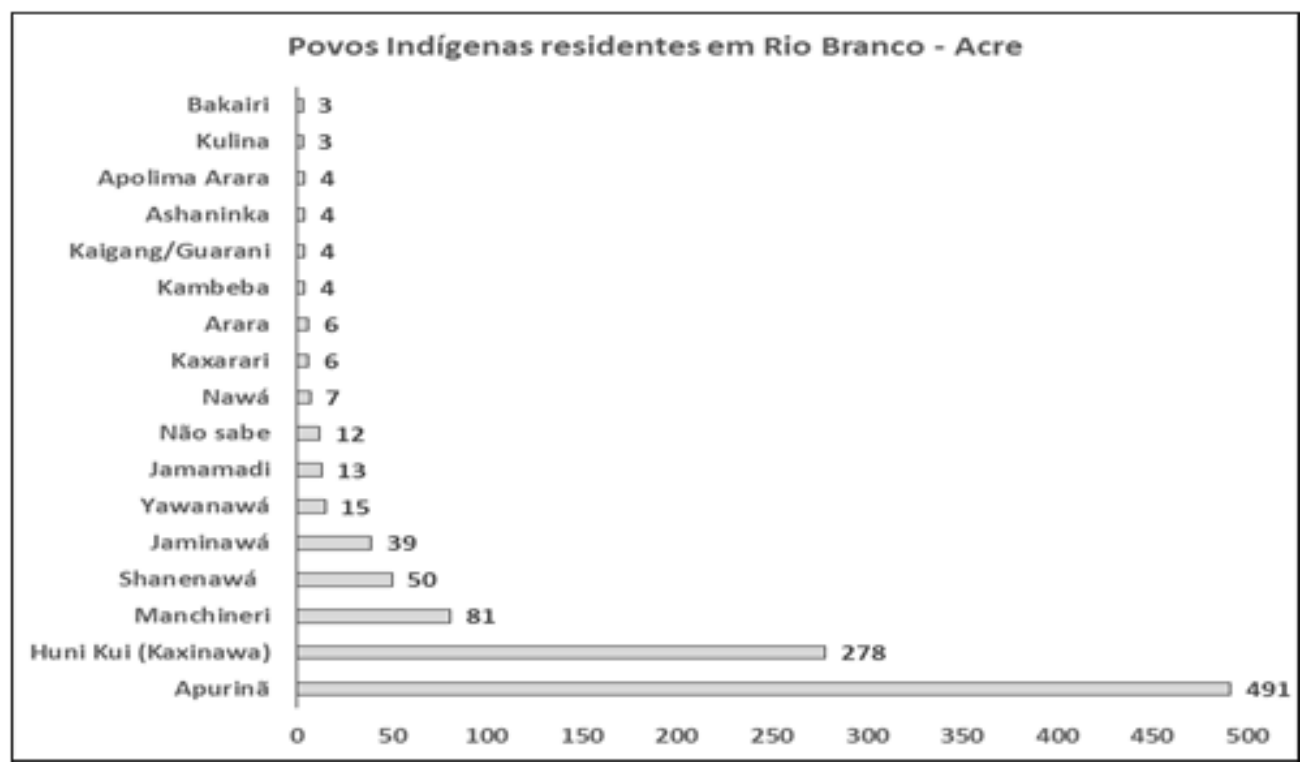

Fonte: CIMI (2012).

Não restam dúvidas que no cenário recente se vê o engajamento dos povos originários em Rio Branco, cidade que se transformou em palco da forte mobilidade humana em decorrência da procura de estabelecimento de direitos, como saúde e educação. Com isso, no cenário urbano a presença de indígenas na cidade é transitória em sua maioria, todavia muito dessa dinâmica se estabelece como permanente.

Também existem indígenas de outras regiões do país residindo em cidades acrianas ${ }^{14}$, como é o caso de algumas pessoas dos povos Kaingang, Guarani e Kambeba. De modo que a presença das lideranças desses povos nas cidades salta aos olhos como proeminente 'novo' cenário, em conformidade com o exposto por Manchinery (2014). Em trabalho de campo para a coleta dados de sua tese de doutorado em Geografia, Manchinery realizou várias entrevistas em 2019 e 2020, que revelaram em que bairros de Rio Branco os indígenas Manchineri da e na cidade se encontravam (Fig. 4). Um total de 90 pessoas e 22 famílias se distribuía por 14 bairros, assim representados: Irineu Serra (2), Apolônio Sales (1), Xavier Maia (1), Placas (2), São Francisco (2), Estação Experimental (1), Baixada da Habitasa (1), Ramal do Amapá (2), Belo Jardim II (3), Vila Acre (1), Sobral (1), Santa Maria (2), Cabreúva (2) e Rosa Linda (1) - todos localizados na periferia da capital acriana e apresentando altos índices de vulnerabilidade social, principalmente violência urbana (Araújo, 2018).

14 Utiliza-se ainda os gentílicos acreana e acreano, em atenção à memória e trajetória da população, de acordo com a Academia Acreana de Letras. 
Figura 4: Distribuição dos Manchineri em Rio Branco, AC.

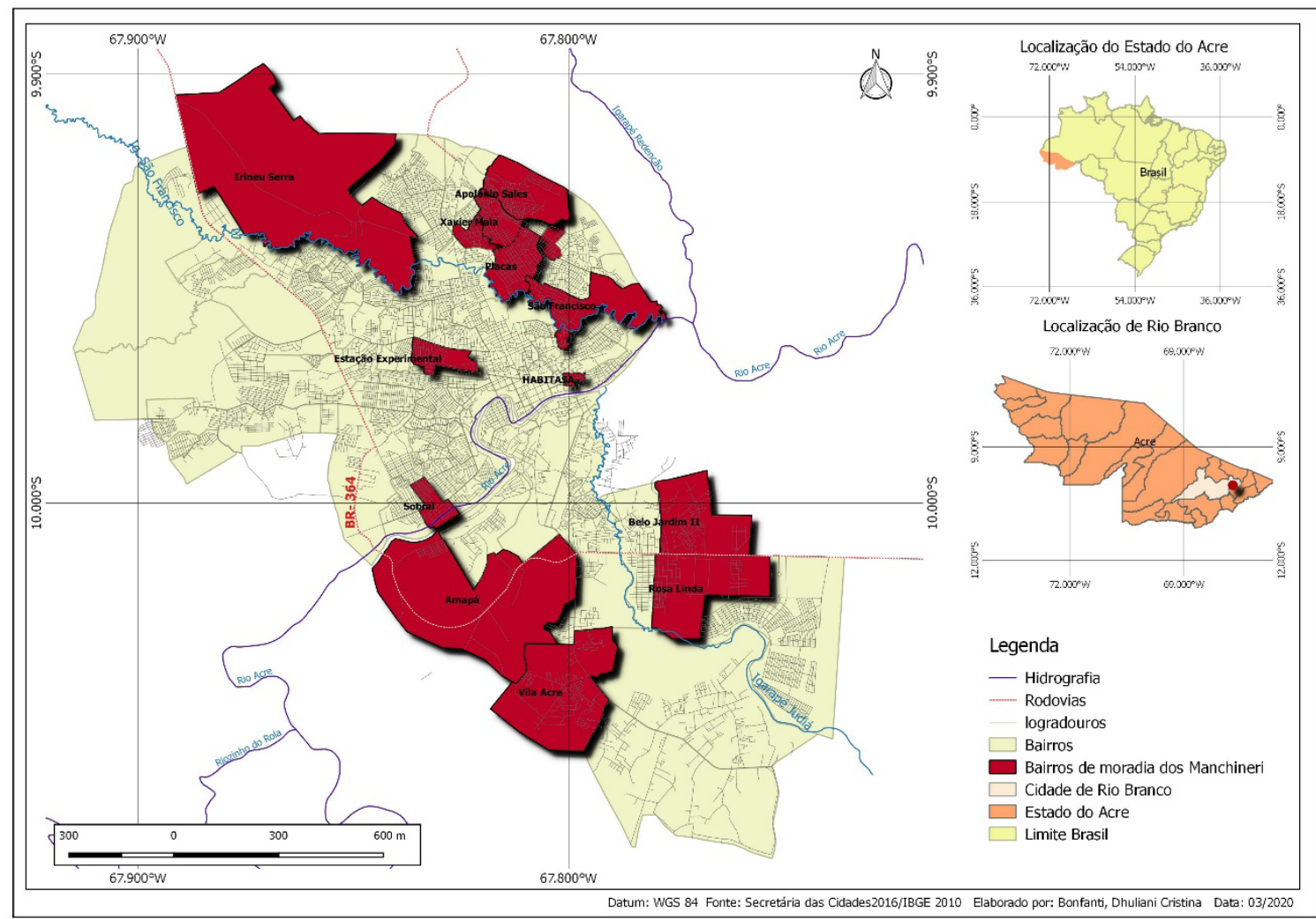

Fonte: Secretaria das Cidades (2006), IBGE (2010).

Em virtude do fenômeno da mobilidade, surgiu uma série de questões desafiadoras que tem se efetivado com intensidade para a Geografia, Antropologia e outras ciências no sentido de explicar o fenômeno. Além disso, existem outras situações igualmente desafiadoras para o poder público e esses atores sociais, como demonstra Manchinery (2014, p.67): "Os 'universos' indígenas do qual eu também faço parte vem se familiarizar e envolver-se, cada dia mais, com processos de mundo do 'branco', como, por exemplo, o consumo, os processos de monetarização, as políticas, até as filiações partidárias".

Em relação às questões sobre filiações partidárias, não teceremos sua análise, mas tratamos como parte das narrativas, visto que os povos indígenas, por terem apreendido os códigos, sentidos e significados da sociedade envolvente, procuram exercer uma unidade discursiva em que a autonomia é sua temática principal, e nela está inserida seu modo de viver, ver e analisar o mundo em suas múltiplas concepções. Resta-nos dizer que para esses povos a política é importante, uma vez que se colocam como protagonistas e têm ocupado seu espaço físico e institucional (inclusive público), onde se inserem com suas vozes e reivindicações até em escala global.

Deste modo, a mobilidade é motivada, em consonância com a avaliação do CIMI (2012), por problemas sociais existentes dentro das aldeias, como a falta da educação escolar indígena de qualidade e, principalmente, atenção à saúde. No caso específico de Rio Branco, esta tornou-se um exemplo de concentração urbana de população indígena e miscigenada. 
Tal condição faz com que a lideranças incorporem uma nova dimensão política, econômica, cultural, e que sejam inseridos na nova ideia de "indígenas urbanizados" (discurso este utilizado para referir que as pessoas indígenas perderam sua cultura; que por morar na cidade não são mais originários). Esse pensamento fere a originalidade e a dignidade dos povos indígenas, como também se cristaliza como a perpetuação do pensamento colonizador. Ponderamos também que é uma incoerência afirmar que o "indígena selvagem", camuflado entre prédios, é pensado como um indivíduo deslocado, fora de seu próprio mundo, em contradição com a essência de seu ser.

Neste sentido, ocorre o hibridismo, isto é o entrelaçamento de distintas culturas, as quais com seus valores permitem a compreensão das mais variadas territorialidades de indígenas nas cidades, o que nos conduz à noção que marca seu território de forma simbólica e imaterial (Almeida Silva, 2007; 2010; 2015). Essa questão nos leva a entender que é uma incorporação de símbolos e representações de outros povos e sociedades, que para além das permanências, também se permite a realização de mudanças, apreensões e percepções de mundo, inclusive de natureza política.

É importante lembrar que, embora os povos originários possam encontrar-se fora de suas terras ancestrais/tradicionais, jamais deixaram de serem indígenas. Destarte, é pertinente destacar que a identidade e a territorialidade não se dissociam dos indígenas, ainda que estejam distantes de si, visto que se trata de

[...] uma dimensão simbólica, cultural, por meio de uma identidade territorial atribuída pelos grupos sociais, como forma de controle simbólico sobre o espaço onde vivem (sendo também, portanto, uma forma de apropriação), e uma dimensão mais concreta, de caráter político-disciplinar: a apropriação e ordenação do espaço como forma de domínio e disciplinarização dos indivíduos (Haesbaert, 2004, p.42).

Compreendemos que os conceitos de espaço e território, mesmo com pertinências distintas, apresentam sintonias de dotação de suas operacionalizações. A territorialidade como sabemos é o resultado do processo da ação humana que ocorre sobre o território. Nele está presente o pertencimento, conforme assegura Bonnemaison (1981, p. 261-262):

Portanto, espaço e território não podem ser dissociados: o espaço é errância, o território é enraizamento. $\mathrm{O}$ território tem necessidade de espaço para adquirir o peso e a extensão, sem os quais ele não pode existir; o espaço tem necessidade de território para se tornar humano.

O tornar-se humano e o pertencimento descritos por Bonnemaison repercutem inclusive no relato de 2014 da indigenista V.O. da CPI/AC ao afirmar que "os motivos que fizeram com os indígenas se descolassem das aldeias para as cidades foi por questões políticas. No caso de seu pai “J.S.S.M"15, foi a luta pela demarcação das Terras Indígenas, atuação do CIMI, e posterior a criação do movimento indígena e outras ONGs, como o Núcleo de Cultura Indígena, e União das Nações Indígenas do Acre e Sul do Amazonas - UNI/AC.

15 Liderança Indígena do Povo Manchineri nas décadas de 1970-1990, que atuou decisivamente para a demarcação da TI Mamoadate, no estado do Acre. 
Complementar ao descrito por V.O. da CPI/AC, J.S.S.M. em entrevista em 2018, confirmou as razões pelas quais teve que fixar moradia na cidade, por entender estrategicamente que necessitava agir politicamente para que se conseguisse algumas vitórias para seu povo e para o movimento indígena acriano e brasileiro: "Saí da aldeia para a cidade porque eu fui convidado para trabalhar no Movimento Núcleo de Cultura Indígena em Rio Branco, depois fui trabalhar no Conselho e Organização Indígena da Amazônia brasileira - COIAB em Manaus, no Conselho de Articulação e Organização Indígena brasileira - CAPOIB em Brasília, e assim foi o passado de minha vida. Comecei a trabalhar no movimento indígena em 1985, e viver na cidade é diferente porque tudo é comprado, até a comida, luz, água, tudo é pago, a pessoa que vive na cidade tem ter emprego próprio e casa própria; na minha luta dentro do movimento indígena fiz muita coisa importante como campanha para a demarcação de terras, e também dei apoio a outras organizações e acampamentos indígenas com parentes de outras regiões, as organizações tinha credibilidade com outros países, hoje não existe mais isso".

Em outras palavras a credibilidade a que se refere, era um apoio maior dentro das aldeias. Como exemplo, J.S.S.M. considera que "antigamente as pessoas que trabalhavam com nós indígenas ia morar dentro das aldeias e aprender como nós vivíamos, hoje os indigenistas aparecem somente de vez em quando, mais nada permanente como antigamente".

Com isso expõe que os desafios são outros e novas demandas surgiram. Neste caso, muitos indigenistas conhecem a realidade indígena superficialmente, o que faz pensar que os indígenas necessitam da concepção de novas estratégias, mas que conservem os antigos aliados e estabeleçam novas parcerias. Essa é a necessidade de se reinventar permanentemente para conquistar novos direitos e autonomia como cidadãos.

\section{LIDERANÇAS INDÍGENAS NA CIDADE}

O processo de urbanização da cidade influenciou uma grande parte dos povos originários no Brasil, fato esse apontado pelo grande número de membros da população indígena morando nos mais diversos centros urbanos (Manchinery, 2014). Aqui avaliaremos a permanência de lideranças indígenas na área urbana no estado do Acre, a partir dos dados de pesquisa feita em 2012 pelo CIMI e de nosso trabalho de campo para este artigo.

A territorialidade urbana de povos indígenas é uma temática estudada por Bernal (2009) e pelo Grupo de Estudos sobre Cartografia Social, coordenado por Alfredo Wagner Berno de Almeida (2010). Para este autor, existem duas modalidades de territorialidade urbana de indígenas: os urbanizados e os na cidade. Os primeiros são aqueles que estão inseridos na vida urbana, enquanto os segundos são aqueles que vivem ou andam pela cidade, porém, mantém fortes trações culturais com sua aldeia ou Terra Indígena. Deste modo, nos interessa discutir as questões das lideranças indígenas na cidade, os quais com seu modo de vida elaboram estratégias de sobrevivência em um ambiente distinto da floresta, bem como relatar essas duas situações.

As territorialidades indígenas na cidade constituem-se em um fenômeno relativamente recente, e ainda pouco estudado no que diz respeito à relação aldeia/cidade. Rio Branco, por ser a capital acriana e maior cidade do estado, recebe continuamente grande 
contingente de migrantes indígenas, o que inclui algumas famílias de lideranças tradicionais. E.S.S.M, em entrevista no ano de 2017, descreve como ocorreu sua chegada na área urbana: "Em 1987 recebi um convite de A. Apurinãa", recém eleito coordenador da União das Nações Indígenas (UNI/AC) para auxiliá-lo na organização. Nessa época, a União da Nações Indígena do Acre e Sul do Amazonas - UNI era registrada como Núcleo de Cultura Indígena (NCI) e só pudemos registrar nossa organização (Acre, sul do Amazonas e noroeste de Rondônia) como UNI após a promulgação da Constituição Federal de 1988 (CF/88), na qual o Estado brasileiro reconhece aos povos indígenas sua organização social, costumes, linguas, crenças e tradições, e os direitos originários sobre as terras que tradicionalmente ocupam (artigo $231 \mathrm{da} C F / 88$ ). No ano de 1989, fui eleito para a tesouraria da UNI/Acre, sendo reeleito em 1996 para mesma função. Antes de completar o segundo mandato fui indicado pela coordenação da UNI/Acre para compor uma chapa com G.Baniwa, M.C. Wanano, D.C. Marubo para concorrer à Coordenação das Organizações Indígenas da Amazônia Brasileira (COIAB), e essa chapa foi eleita para o biênio 1996 a 1998. Na COIAB, fui eleito diretor de Áreas de Direitos Humanos e Políticas Sociais da Coordinadora de Las Organizaciones Indígenas de La Cuenca Amazónica (COICA), para o quadriênio 1997-2001. Em 2003, fui indicado pelas lideranças indígenas do Acre, sul do Amazonas e noroeste de Rondônia para a Comissão Nacional de Política Indigenista (CNPI), ligada ao Ministério da Justiça (MJ). Mais recentemente, em 2008, fiz parte do Grupo de Trabalho Interministerial (GTI) que teve por objetivo elaborar proposta da Política Nacional de Gestão Territorial e Ambiental em Terras Indígenas - PNGATI, instituída pelo Decreto $n^{0}$ 7.747, de 5 de junho de 2012. Em dezembro de 2011, por indicação da Coordenação das Organizações Indígenas da Amazônia Brasileira - COIAB, fui indicado para compor a equipe da Deutsche Gesellschaft für Internationale Zusammenarbeit (GIZ) GmbH. Minha função foi coordenar o processo de sistematização e disseminação dos projetos apoiados pelo Projeto Demonstrativo dos Povos Indígenas (PDPI), executado pelo Ministério do Meio Ambiente (MMA) com recursos destinados às comunidades, povos e organizações indígenas. Os recursos foram provenientes do Ministério Federal de Cooperação Econômica e Desenvolvimento da Alemanha por meio do Banco KfW, tendo a assistência técnica da GIZ. Em 2015, sou contratado pela Faculdade Latino-Americana de Ciências Sociais - FLACSO, como mobilizador nacional indígena para a Primeira Conferência Nacional de Política Indigenista - CNPI. Foram oito meses de intensa mobilização e consultas locais e regionais aos povos indígenas do Brasil, as atividades foram concluídas com a realização da Conferencia de Política Indigenista, que ocorreu na cidade de Brasília no período de 14 a 17 de dezembro de 2015".

Para além deste relato, dirigimos algumas perguntas para E.S.S.M., tais como: a) como ocorreu sua fixação na cidade?; b) como era (e ainda é) possível explicar tais processos sem levar em conta o protagonismo indígena?; c) como entendíamos a vitória e o domínio dos portugueses sobre milhares de povos guerreiros?; d) como explicávamos o sucesso de apenas duas das várias capitanias hereditárias, quando as outras soçobravam diante dos ataques indígenas?; e) como podiam alguns degredados ocupar postos chaves nas sociedades nativas, que lhes permitiram fornecer o imprescindível auxílio aos portugueses?; f) como conseguiam dois missionários controlar centenas de índios nas aldeias coloniais?; g) como explicávamos essas e tantas outras questões de nossa história 
sem considerar o protagonismo indígena?; h) como e por que vários povos considerados extintos e, por longo tempo, excluídos da História do Brasil ressurgem, hoje, no cenário político e acadêmico do país?.

Em resposta, E.S.S.M. considerou que os povos indígenas são sim seus próprios protagonistas, construtores de sua história, que através das lutas ainda sobrevivem. Acrescentou que: "Bom, estudar na cidade não é fácil para ninguém que vem do interior, principalmente sendo indígena. Nosso país ainda é muito preconceituoso, a prática do preconceito é feita por pessoas comuns, mas também por autoridades. Estes pensam que o "Índio" verdadeiro é aquele que está pintado com cocar. Nesse sentido, lembro de uma frase do J.C. Jaminawa ${ }^{17}$, que diz que, o indio pode pintar o cabelo de loiro, colocar uma boa roupa, mas sempre o parente o conhece pelo pé, ou seja, sua identidade biológica não muda. Então, como trabalha, penso que seja divulgando cada vez a cultura indígena, a contribuição de nosso povo na culinária, no mundo espiritual, na medicina e principalmente não se deixando ser sacaneados pelos não índios. Os "tipos" de indios, os que andam caracterizados ou a "paisana" disse um segurança da Câmara dos Deputados. Penso que seu povo ainda utiliza as pinturas corporais, cocares no dia a dia, então você não estará fazendo tipo. Agora se seu povo já não utiliza essa parte da identidade, então você estará fortalecendo aos não indigenas a criar esses "tipos" de indios de "verdade", que não estão contribuindo para a valorização da identidade indígena".

Através do relato é possível identificar nas palavras do entrevistado que existe uma construção colonizadora do que seja o 'índio verdadeiro' para a sociedade 'branca'. E que esta considera que verdadeiro é aquele que anda com pinturas corporais e cocares em seu cotidiano, pois somente assim se demostra como real.

Predominantes em nossa historiografia e continuamente alimentada pela mídia e pelas narrativas históricas em escolas, colégios e universidades, essas ideias foram facilmente incorporadas no imaginário da população brasileira, com imensos prejuízos para todos, mas principalmente para nós indígenas. Somos duplamente violentados, pois além de termos enfrentado as trágicas consequências dos processos históricos vivenciados, sofremos ainda os efeitos da violência secular adotada no país, na qual figuramos em papéis secundários e depreciativos, entre as posições de vítimas passivas, bons selvagens ou bárbaros.

O historicídio, nas palavras de Almeida (2017), contribuiu e contribui para reforçar em nossa sociedade ideias preconceituosas e estereotipadas sobre os povos originários. Estes "valores" são muito presentes no senso comum da população brasileira, essas ideias, além de extremamente danosas à autoestima e modo de vida indígenas, reforçam os sentimentos preconceituosos e discriminatórios que resultam em atitudes de intolerância e violência praticadas pela sociedade envolvente contra os povos originários.

Desconstruí-las é tarefa essencial de todos. É o que tem sido feito nas últimas décadas, com resultados ainda bastante obtusos e incipientes em face das imensas dificuldades em demolir concepções tão profundamente arraigadas.

Não se trata apenas de repensar a trajetória e mobilidade dos povos indígenas em situações de contato, como tem sido feito por inúmeras pesquisas em diferentes regiões

17 Liderança do Povo Jaminawa no Acre. 
do país. O mais difícil e fundamental é incorporar essas pesquisas para repensar a própria história e a geografia brasileiras.

A Geografia tem contribuído muito pouco com as abordagens e temáticas indígenas em contexto científico e grades curriculares, ou seja, na promoção da visibilidade dos saberes desses povos. Acreditamos que seja necessário decolonizar o discurso acadêmico, visto que de modo contínuo seus estudos têm primado pela narrativa do pensamento ocidental. Entendemos que a partir da formação de cada pessoa e com a introdução de seus estudos que focalizem a temática dos povos originários, poderá ser amenizada a ausência de conhecimentos acerca dessas populações, que possuem ricas culturas e contribuem para o desenvolvimento do país e da humanidade.

A propositura desse item é um passo importante nessa direção, todavia sabemos que a realidade, de fato, não se divide, e a compartimentalização do saber em vários campos de estudo atende à necessidade de especialização. Diante da complexidade dos objetos de análise, que exigem recortes cada vez mais aprofundados em seus aspectos temático, temporal e espacial, esta exigência faz com que os assuntos relacionados aos povos indígenas sejam mal interpretados e entendidos em várias áreas do conhecimento. Daí a importância do diálogo contínuo entre os especialistas, academias, pesquisadores e os próprios indígenas, de maneira a superar interpretações estanques que limitam as possibilidades de análise. Neste sentido, precisamos avançar e mostrar que a atuação dos povos originários na geo-história do Brasil foi e é fundamental.

Deste modo, apresentamos as lideranças que fizeram história (Quadros 1 e 2) e que contribuíram com a geo-história do Acre e na formação política do movimento indígena.

O primeiro se refere às lideranças entre os anos 1983 a 1990, e que foram precursores na construção do movimento no Acre, que sem nenhum financiamento dos órgãos públicos saíram de suas terras tradicionais pela luta e demarcação de suas terras. O outro refere-se dos anos 1990 até a atualidade, que com muita batalha conquistaram parceiros internacionais (http:/ / cpiacre.org.br/cpi-acre/parceiros-e-apoios/) que contribuíram para com sua atuação em Brasília e na Amazônia acriana. Assim eles objetivam o fortalecimento do movimento indígena, enquanto mecanismo de conquistas de direitos.

Quadro 1: Lideranças Tradicionais Indígenas entre os anos 1983 a 1990.

\begin{tabular}{|l|l|l|l|}
\hline Liderança & Povo/Etnia & Liderança & Povo/Etnia \\
\hline A. Apurinã & Apurinã & J.Z.M. Apurinã & Apurinã \\
\hline A.C.Kaxarari & Kaxarari & J.S.S. Manchineri & Manchineri \\
\hline A.F. Apurinã & Apurinã & L. Apurinã & Apurinã \\
\hline B.B.Shanenawa & Shanenawa & M. Apurinã & Apurinã \\
\hline F.B. Kaxinawa & Kaxinawá & R.S. Yawanawa & Yawanawa \\
\hline F.G.Apurinã & Apurinã & R. Nukini & Nukini \\
\hline G.S. Kaxinawa & Kaxinawá & S.S. Kaxinawa & Kaxinawá \\
\hline J.C. Jaminawa & Jaminawa & V.S. Kaxinawa & Kaxinawá \\
\hline J.M. Apurinã & Apurinã & & \\
\hline
\end{tabular}

Nos anos 1980-1990 haviam 17 lideranças que correspondiam a nove povos originários, ao passo que a partir de 1990 passou-se a ser representado por 14 líderes, entre as 
quais duas mulheres indígenas, com o número de representação por etnia reduzido para sete. As mulheres têm cargos na direção das entidades, inclusive existe uma organização própria delas para cuidar de suas pautas de reivindicações e conseguido algumas importantes conquistas, as quais beneficiam vários povos em sua área de atuação. No entanto, ainda é necessário maior engajamento e fortalecimento institucional.

Constata-se ainda que poucas lideranças continuaram à frente do processo, o que em tese evidencia o enfraquecimento do movimento indígena no Acre ou que as organizações perderam parte de seu protagonismo ou credibilidade dentro e fora do país, conforme mencionado por J.S.S.M. na descrição da seção anterior.

Quadro 2: Principais Lideranças do Acre na atualidade

\begin{tabular}{|l|l|l|l|}
\hline Liderança & Povo/Etnia & Município & Organ./Associação18 \\
\hline A. Apurinã & Apurinã & Boca do Acre/AM & \\
\hline C.B. Shanenawa & Shanenawa & Feijó/AC & \\
\hline F.Apurinã & Apurinã & Boca do Acre/AM & CNPI \\
\hline E.S.S. Manchineri & Manchineri & Assis Brasil/AC & \\
\hline F. A. Shawadawã $\left(^{*}\right)$ & Shawadawã & Cruzeiro do Sul/AC & AMAIAC \\
\hline J.M Huni Kũ & Huni Kũ̃ & Taraucá/AC & Liderança tradicional \\
\hline J. Yawanawá & Yawanawá & Taraucá/AC & Organ. Yawanawá \\
\hline J.C. Jaminawa & Jaminawa & Sena Madureira/AC & FUNAI \\
\hline J.S.S. Manchineri & Manchineri & Sena Madureira/AC & Liderança Tradicional \\
\hline L.Yawanawá $\left(^{*}\right)$ & Yawanawá & Taraucá/AC & SITOAKORE \\
\hline M.G. Huni Kuĩ & Huni Kũ & Taraucá/AC & Liderança tradicional \\
\hline N. Huni Kũ̃ & Huni Kũ & Feijó/AC & FHEPAK \\
\hline S. Manchineri & Manchineri & Assis Brasil/AC & MAPKAHA \\
\hline S.Huni Kũ̃ & Huni Kũ & Jordão/AC & \\
\hline
\end{tabular}

(*) Lideranças femininas.

Frente as considerações e análises feitas até aqui, é preciso destacar as dificuldades de atuação da Funai e dos demais órgãos públicos frente às demandas das populações indígenas no país, em particular na Amazônia e no Acre, o que contribui muitas vezes para a não permanência de parte de membros desses em seus territórios e a fixação nas áreas urbanas.

Entre os vários fatores que contribuem para isso, estão a restrição orçamentária e financeira para atividades de fiscalização, monitoramento e vigilância territorial, a falta de recursos humanos para atividades afins, insuficiência de infraestrutura física e de transporte (veículos, barcos) dentre outros. É oportuno considerar ainda que a maioria das TIs na região encontra-se distantes dos centros urbanos, e aquelas que podem ser acessadas

18 Associação do Movimento de Agentes Agroflorestais Indígenas do Acre (AMAIAC); Conselho Nacional de Política Indigenista (CNPI); Federação do Povo Huni Kuĩ (FHEPAK), que tem objetivo o fortalecimento deste em todo o Estado do Acre; Fundação Nacional do Índio (FUNAI); Manxinerune Photi Kajpaha Hajene (MAPKAHA); Organização das Mulheres Indígenas do Acre, Sul do Amazonas e Noroeste de Rondônia (SITOAKORE). Para além destas, a Comissão Pró-Índio do Acre (CPI/ AC) aponta um total de 21 organizações indígenas naquele Estado. A mesma fonte apontava em 2016 a existência de uma população aproximada de 17 mil indígenas distribuída em cerca de 200 aldeias e 36 terras indígenas reconhecidas; 15 povos pertencem a três famílias linguísticas (Pano, Aruak e Arawá); área total estimada em 2.439 .982 hectares (16\% do território acriano). Conta ainda com povos isolados e um povo de recente contato que se autodenomina Tsapanawa. 
por vias terrestres em sua maioria se dão por estradas não pavimentadas que oferecem precárias condições de trafegabilidade, especialmente no período chuvoso na região (de outubro a abril).

A falta de recursos restringe ainda atendimentos na área educacional (limitadas e excepcionalmente em algumas poucas aldeias das TIs até o $9^{\circ}$ ano do ensino fundamental) e de saúde, vistas como gargalos e motivo de preocupações dos pais indígenas para com seus filhos. Com isso obrigam-se a procurar melhores oportunidades para as famílias, inclusive relacionadas a trabalhos e rendas no meio urbano.

Em síntese pode-se afirmar que esses e outros fatores ocorrem pela fragilidade institucional do poder público, que contribui para que parcela das populações originárias que moram nas TIs se fixem nas cidades temporária ou permanentemente. Assim ocorre um rebatimento social com acumulação de problemas no meio urbano, além dos já existentes. Nem todos os que saem de suas aldeias encontrarão oportunidades de trabalho, renda, moradia, acesso à saúde e à educação, dentre outras demandas que são importantes direitos de cidadania.

\section{LIDERANÇAS: POLÍTICAS INDÍGENAS E INDIGENISTAS}

A entrevista em 2017 de E.S.S.M. permite avaliar que não se trata de uma política indígena, mas de ações dos povos originários que se baseia na retomada e ocupação de seus territórios em sua maioria, visto que perderam seus locais de caça, de pesca, de agricultura ancestral, de moradias, espirituais, dentre outros, durante o processo de ocupação e colonização.

Neste sentido, entendemos que a narrativa presente na entrevista de E.S.S.M. aproxima-se da definição de áreas de intersecção oportunizada por Sobreiro Filho (2013, p.49), pois se tratam de "são espaços de contato em que as estruturas e relações se aproximam e podem potencializar uma transformação, o vir-a-ser em movimento socioterritorial".

No caso em questão, refere-se à política e a constituição de parcerias, de formulação estratégica que podem oportunizar a conquista e a garantia de direitos. Na Amazônia, os Manchineri tiveram a oportunidade de iniciar os Planos de Vidas, o Plano de Gestão Territorial e Ambiental (PGTA), para que assim se pudesse pensar trabalhar os recursos naturais em benefício da geração presente e futura. Assim, E.S.S.M. expôs na entrevista em 2017, que "Não podemos chamá-la de uma política indígena para isso teríamos que ter um Plano Indígena que se incorporasse as várias realidades de nossos povos originários, que vai desde o grau de contato com a sociedade nacional, o contexto econômico e político que vive e sua organização social. Ou seja, um plano que contenha objetivos, metas e resultados onde, nós povos indígenas queremos chegar e ser no futuro".

Por esta constatação, tem-se que o Estado brasileiro, e grande parcela da sociedade envolvente, não tem se sensibilizado com as questões indígenas e com as minorias que dependem das terras e da garantia de territórios para sua sobrevivência. Fica evidente que as políticas indigenistas deveriam ser feitas para atender aos cidadãos menos favorecidos, 
ou seja, que todos fossem beneficiados, independentemente de sua especificidade, sua realidade geográfica. Como exemplo, o Programa Bolsa Família atende as populações que vivem nas periferias urbanas, entretanto para ribeirinhos, extrativistas e indígenas os benefícios deveriam possuir outros critérios, pois essas populações vivem distante dos centros urbanos e com dificuldades de acesso, principalmente na Amazônia.

Na consideração de E.S.S.M é enfatizado que grande parte das políticas indigenistas não olham para as diferentes realidades das diversas populações, especialmente a indígena, pois são estes que tem que se adequar às políticas e não ao contrário. Em sua avaliação, entende que a política pública que mais se aproximou da realidade dos povos originários foi a Política Nacional de Gestão Territorial e Ambiental de Terras Indígenas (PNGATI), construída com a participação de lideranças e organizações indígenas, de ONGs e do poder público. Entretanto, essa política tem sofrido descontinuidade, seja por falta de recursos, seja pela incapacidade ou omissão dos governantes em implementá-la.

Ainda para o entrevistado, a luta dos povos indígenas é árdua e constante, pois o desconhecimento da realidade local, regional e nacional dessas populações resulta em sérias consequências nas formulações de políticas de ações afirmativas e garantias de seus direitos. Com a constante violação de seus direitos, a existência de pressões, invasões aos territórios e ameaças de várias outras ordens, muitas vezes os acirramentos culminam em agressões físicas e, em casos mais extremados, até mesmo assassinatos. Muitas lideranças indígenas que lutaram na defesa do meio ambiente e das terras tradicionalmente habitadas por eles, por exemplo, têm sofrido constantes ataques, em suas terras, de criminosos, invasores, madeireiros, garimpeiros, dentre outros.

Dados da CPT Nacional (2020), afirmam que nos 13 primeiros dias de 2020, indígenas e quilombolas foram vítimas de assassinatos e ataques que deram continuidade à escalada de violência que atingiu os povos tradicionais e originários no ano passado, entre eles pessoas do povo Guajajara e Guarani. Em Rondônia ${ }^{19}$, no mês de abril de 2020 foi assassinado uma liderança Uru-Eu-Wau-Wau, possivelmente, motivado por conflitos relacionados à terra, visto ser a TI Uru-Eu-Wau-Wau uma das mais visadas pelos invasores.

Mediante tais constatações, as lideranças indígenas traçam suas estratégias de atuação com a finalidade de sua sobrevivência física, cultural e espiritual, bem como de suas terras, por meio de suas organizações e de parceiros que contribuem na causa (Fig. 5).

19 Para além das mortes relacionadas a conflitos, na Amazônia em 2020 faleceram várias pessoas indígenas dos mais diferentes povos, inclusive lideranças, devido ao vírus da COVID-19. Tal fato tem um forte impacto na vida das coletividades originárias, de modo que representa em alguns dos povos o apagamento de suas histórias, de suas culturas. 
Figura 5: Estratégias de lideranças indígenas percebidas nesta pesquisa.

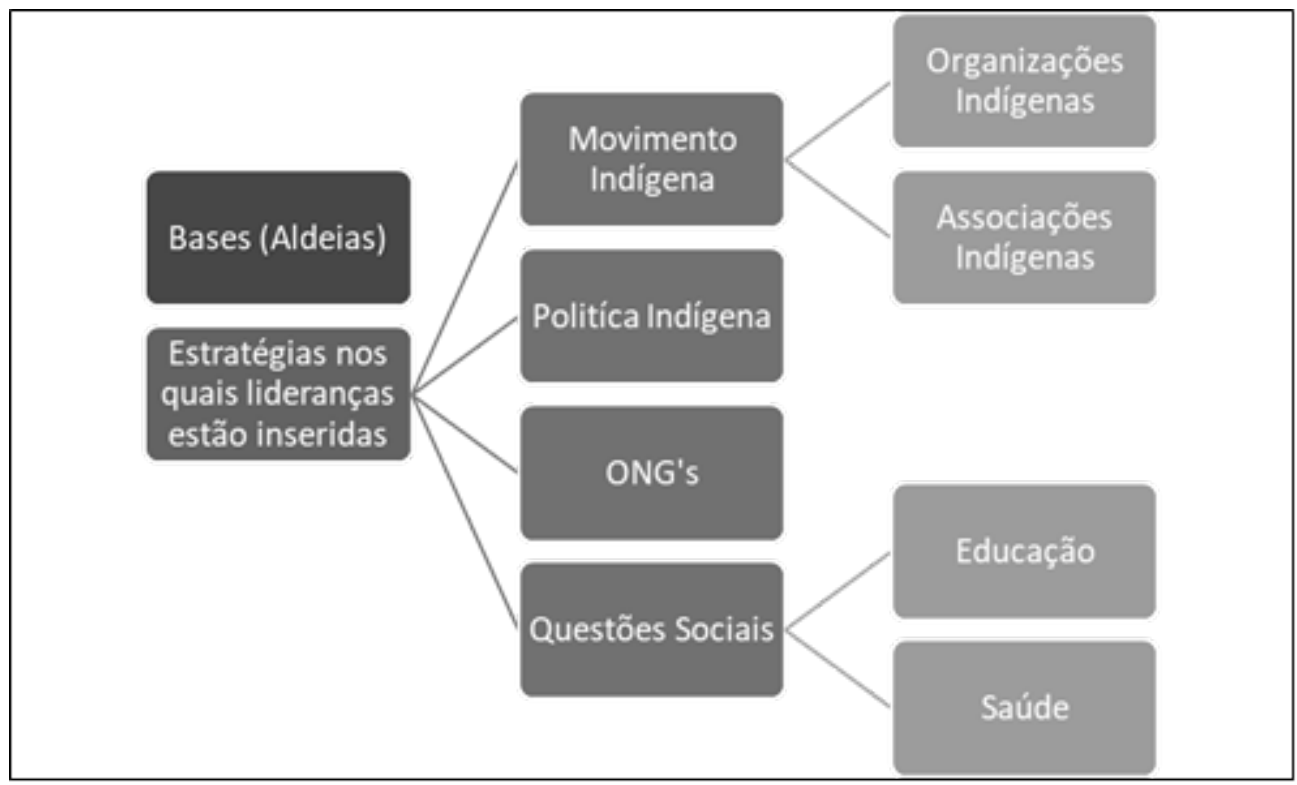

A explicação de uma das estratégias das lideranças é sua inserção primeiro se articulando nas bases (aldeias); em seguida são apresentadas para os movimentos, organizações e associações, onde se discutem as possíveis repercussões que as propostas podem apresentar como benefícios e impactos negativos. Diante dos cenários que se colocam, assim constituem a política indígena, bem como buscam meios para tentar solucionar questões relacionadas à Educação, à Saúde, dentre outras. Isso evidencia a necessidade de acessar constantemente o meio urbano, visto que é lá que se encontra o poder público e possíveis apoiadores.

Outra percepção foi oportunizada pelo líder J.S.S.M., em entrevista em 2018, de que a política indígena está muito fraca porque a maioria foi trabalhar no governo e com isso as organizações indígenas não possuem mais força para cobrar seus direitos. $\mathrm{Na}$ sequência comenta que existe uma grande diferença entre a política indígena e a política do 'branco': "Na política do branco, eles se candidatam, e o povo vota neles, e eles também fazem muitas promessas, mas quando eles chegam no poder viram as costas para os eleitores aí começa a roubarem dinheiro das nações, somente pensando em si mesmo. A politica indigenista é um braço do Governo Federal porque foi quem criou isso, não foi nós indígena, foi aí que o governo contratou muito indigenista para trabalharem com nós indígenas, e fazerem uma política indígena que na verdade os indigenistas em sua maioria fazem uma política do governo".

Diante das questões mencionadas, as quais devem ser abordadas de modo articulado e complexo, pela história indígena e pela história da escravidão que tivemos ao longo da invasão em solo brasileiro, precisamos propiciar novas leituras sobre as relações de poder desde a colônia até à atualidade. Reportamo-nos à inclusão de lideranças indígenas como sujeitos de sua própria história de luta e também de seus conhecimentos, políticas e cosmociências.

Destacamos a necessidade de reconhecer os interesses políticos dos vários povos envolvidos nos acordos estabelecidos com os políticos não-indígenas. As variadas motivações 
que impulsionavam e impulsionam os povos originários (das e nas cidades) a estabelecer múltiplas e inconstantes relações de aliança com determinados partidos políticos, geralmente ao logo dos anos, tem gerado uma série de conflitos entre povos indígenas e a sociedade envolvente. Entre eles, outros agentes identificados por inúmeras pesquisas interdisciplinares que buscam desvendar os significados próprios que são atribuídos nos acordos.

Assim há uma possível alternativa, que o indígena considera seus próprios códigos culturais, suas percepções, suas lógicas cognitivas e suas vivências construídas e modificadas na dinâmica de suas interações, como parte integrante do processo. Essa é uma estratégia de sobrevivência que almeja garantir assim sua permanência em diversos territórios.

Assim, para entender como se dá a entrada de indígena no seio da política, concordamos com Berstein (1998, p.350), quando afirma que a política "não é uma chave universal que abre todas as portas, mas um fenômeno de múltiplos parâmetros, que não leva a uma explicação unívoca, mas permite adaptar-se à complexidade dos comportamentos humanos". Trata-se de uma "espécie de código e de um conjunto de referentes, formalizados no seio de um partido ou, mais largamente, difundidos no seio de uma família ou de uma tradição política" (Berstein, 1998, p.350):

Por meio da política indígena os povos originários concebem seu mundo, numa visão comum, dentro de uma lógica coletiva ou comunitária como organização sociopolítica, na qual se fundamentam na cultura e espiritualidade. Com isso se torna possível sua coesão política interna, de modo a permitir suas mais variadas representações. Para Berstein (1998, p.362-363) o coletivo vai a se configurar "em normas, crenças, valores que compõem um patrimônio indiviso, fornecendo-lhes, para exprimir tudo isto, um vocabulário, símbolos, gestos, até canções que constituem um verdadeiro ritual".

O sentido dado pelo autor aproxima-se do conceito de cultura defendido por Dardel (2011 [1952]) ao tratar da relação estabelecidos dos seres humanos com a terra, visto que esta é sua moradia, dela tira o sustento para sua sobrevivência, além de estar presente relações que implicam em exercício do poder:

[...] a ligação do homem com a terra recebeu, na atmosfera espaço-temporal do mundo mágico-mítico, um sentido essencialmente qualitativo. A geografia é mais do que uma base ou elemento. Ela é um poder. Da terra vêm as forças que atacam ou protegem o homem, que determinam sua existência social e seu próprio comportamento, que se misturam com sua vida orgânica e psíquica, a tal ponto que é impossível separar o mundo exterior dos fatos propriamente humanos. (Dardel, 2011, p.48 [1952].

Somado à esta abordagem é que temos o conceito de "marcadores territoriais" defendida por Almeida Silva (2010; 2015), como possibilidade de compreendermos e analisarmos as relações estruturantes que são marcadas por padrões socioculturais e pelas necessidades humanas, nos quais a mobilidade e o protagonismo indígena são construídos, visto que:

[...] a partir dos símbolos que ocorrem enquanto espaço de ação, definem territorialidades vinculadas à cosmogonia e experiências socioespaciais e possibilitam a formação das identidades culturais e do pertencimento identitário. Sendo assim, os "marcadores territoriais" são experiências, vivências, sentidos, sentimentos, percepções, 
espiritualidade, significados, formas, representações simbólicas e presentificações que permitem a qualificação do espaço e do território como dimensão das relações do espaço de ação, imbricados de conteúdos geográficos. (Almeida Silva, 2010, p.105; Almeida Silva, 2015).

Como resultado da familiarização da cultura política é que apresentamos a Figura 6, com as percepções e lógicas do pensamento indígena, na qual a contribuição de J.S.S.M., em 2018, foi esclarecedora no sentido de diferenciar "marcadores territoriais", ou seja, o olhar interno coletivo político do povo Manchineri e os "demarcadores territoriais", isto é, a política externa ou indigenista.

Neste caso tem-se duas visões distintas sobre a questão indígena, todavia é possível compatibilizá-las para obtenção da autonomia. Ressalta-se que não se trata de arranjos ou de pactos fáceis, visto que nem sempre os agentes públicos possuem sensibilidade necessária para o desenvolvimento de ações, até mesmo em razão de temporalidades e a relação com a natureza e a terra terem distintas representações, sentidos e significados.

Figura 6: Diagrama da diferença entre política indigenista e indígena.
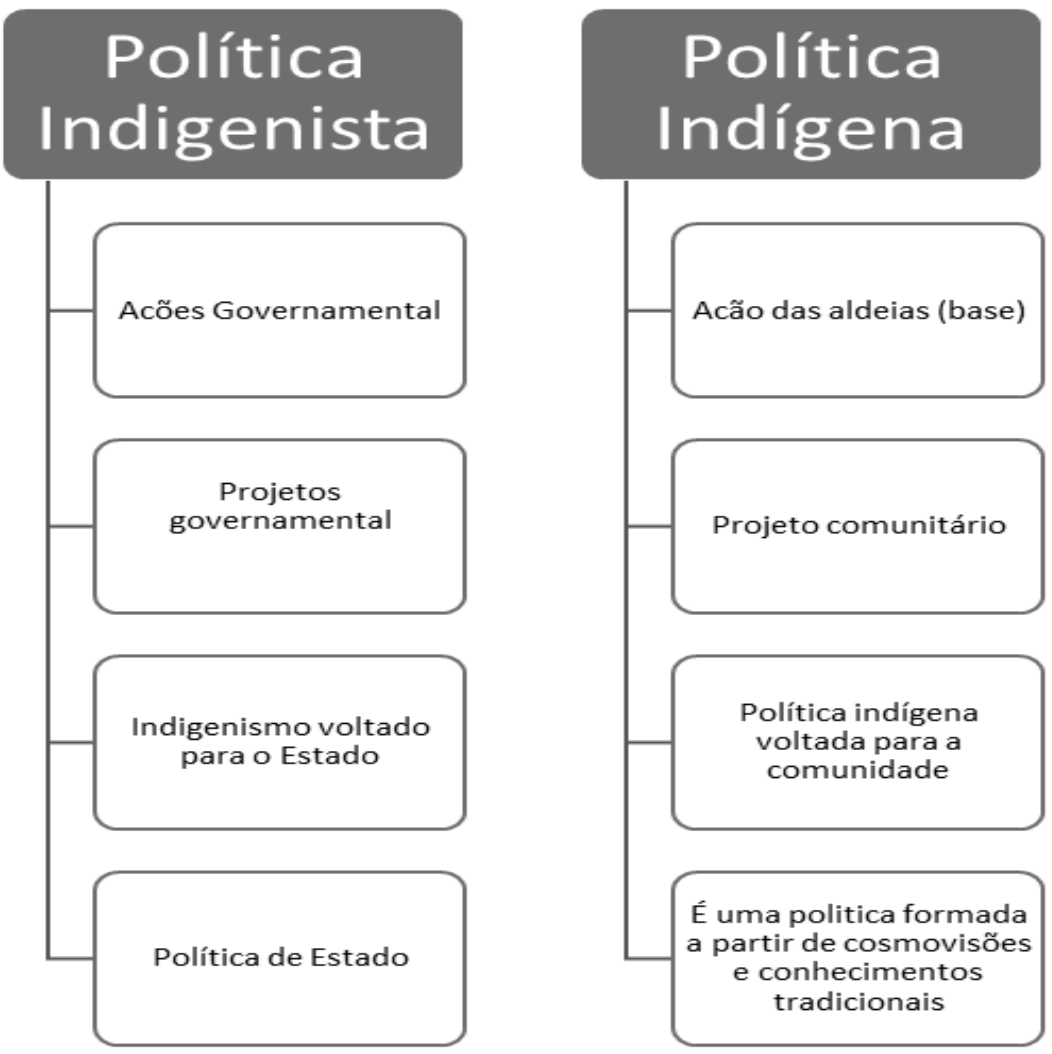

Se acordadas dentro do aceitável, essas políticas indígenas e indigenistas, poderão minimizar a problemática da mobilidade dos líderes, de suas famílias e consequentemente das pressões, dos conflitos, das constantes ameaças que sofrem os povos originários. 


\section{CONSIDERAÇÕES FINAIS}

Resta-nos discutir o que foi abordado neste trabalho, ressaltamos que pouco se tem avançado tanto historiográfica quanto em questões políticas, as quais mesmo em vários campos do conhecimento, assim caminham juntas e influenciam-se mutuamente. A história e geografia, na percepção indígena, tem-se beneficiado pelo desenvolvimento de pesquisas em diversas áreas, com isso renova-se continuamente, produzem conhecimentos que possibilitam repensar várias outras temáticas que envolvem os povos originários brasileiros, como procuramos demonstrar ao longo deste trabalho.

Ao retomarmos as considerações da perspectiva indígena vale lembrar que ainda temos muito que avançar, sobretudo, no sentido de conectar histórias, culturas e a política. Uma vez que são poucos os pesquisadores que se interessam por esses temas, há um alto custo para esses povos e para esses estudiosos, devido às barreiras que são impostas pelo poder público e a sociedade envolvente, que dificultam em parte o avanço nas conquistas dos direitos indígenas.

Mantemo-nos na perspectiva de que os estudos, pesquisas e práticas sejam mais frequentes, sobretudo nas questões em que envolvem a ciência geográfica. Não temos dúvidas que muitas outras revisões bibliográficas deverão ser feitas, muitas páginas das geografias e histórias desses povos originários serão reescritas a partir de suas percepções/ realidades, e não por terceiros que muitas vezes desvirtuam ou não conseguem apreender as representações, vivências e os sentidos experimentados pelos indígenas. Quem sabe os povos originários, talvez, possam ter um futuro mais promissor e com melhor aceitação na sociedade do homem 'branco'.

Esta última observação aponta para o fato de que, para além da contribuição acadêmica aqui apresentada, é importante considerar os indígenas como protagonistas de suas histórias, culturas, saberes e ciências, ou seja, a conquista de sua autonomia e cidadania do ponto de vista social e político, dentre outros valores importantes para o desenvolvimento do país.

Neste momento, a primeira autoria apresenta sua reflexão em se colocar como mulher indígena, que segue o caminho do antigos Manchineri, seu povo. Colocada num caminho pela luta e resistência, diante dos diversos obstáculos tenta de maneira integral trazer para seus trabalhos autores que não se limitem ao pensamento estruturado do mundo ocidental - quase impossível, uma vez que é raro autores dos povos originários que discutem a epistemologia geográfica.

Por outro lado, devemos neste caso reconhecer as atuações indígenas na Geografia e na História do Brasil, com respeito a restituição de sua condição de sujeitos às novas interpretações que apresentam-se como essenciais para desconstruir ideias preconceituosas e deturpadas ainda muito presentes na sociedade, sobretudo em regiões próximas às TIs e nas áreas urbanas habitadas por essas populações originárias.

Para além disso, o conhecimento do passado e de suas próprias trajetórias é um relevante instrumento de luta para os povos originários, que desde o período colonial têm lançado mão desse recurso para reafirmarem seus direitos e perpetuar seu modo de vida 
tradicional. Para além disso, há com muito esforço e determinação, vários indígenas que conquistaram espaços em faculdades, universidades e programas de pós-graduação, de modo a escrever suas próprias narrativas históricas. Contribuem assim com as ciências e, acima de tudo, descontroem ideologias e ideias equivocadas sobre esses povos. Assim, buscam se capacitar para substituir discursos de oposição e violência pelo apoio às suas causas.

Para finalizar, acreditamos que os não-indígenas precisam repensar os modos de ver o Outro como diferente, e até mesmo como adversário, mas considerá-los como atores sociais importantes na constituição do território nacional e relevantes para o desenvolvimento com qualidade de vida, respeito e oportunidades para todos que habitam nosso Planeta.

\section{AGRADECIMENTOS}

Apoio: Programa de Apoio ao Pesquisador Rondoniense (PQR), Chamada 003/2017/ PQR/FAPERO, Outorga 042/2017, Protocolo 33897.521.20813.06102017, por meio do projeto Geografia e Marcadores Territoriais: Sentidos e Representações Socioculturais Amazônicas, e Grupo de Pesquisa Geografia, Natureza e Territorialidades Humanas - GENTEH/UNIR.

\section{REFERÊNCIAS}

Almeida, A.W.B. et al. (Orgs.) (2010). Manaus: Projeto Nova Cartografia Social da Amazônia. Manaus: UEA. (Cadernos de debates Nova Cartografia Social: Territórios quilombolas e conflitos, v.1, n. 2). Recuperado de http:/ / novacartografiasocial.com.br/download/02-territorios-quilombolas-e-conflitos/

Almeida, M.R.C. (2017) A atuação dos indígenas na História do Brasil: revisões historiográficas. Revista Brasileira de História, 37(75):17-38. https:/ / doi.org/10.1590/1806-93472017v37n75-02

Almeida Silva, A. (2007). Impactos socioculturais em populações indígenas de Rondônia: estudo da nação Jupaú. (Dissertação de Mestrado em Geografia). Universidade Federal de Rondônia, UNIR, Porto Velho, RO, Brasil. Recuperado de http://www.mestradogeografia.unir.br/downloads/3220_adnilson_de_almeida_2006. pdf

Almeida Silva, A. (2010). Territorialidades e identidade dos coletivos Kawahib da Terra Indígena Uru-Eu-WauWau em Rondônia: "Orevaki Are" (reencontro) dos "marcadores territoriais". (Tese de Doutorado em Geografia). Universidade Federal do Paraná, UFPR, Curitiba, PR, Brasil. Recuperado de https://acervodigital.ufpr. br/bitstream/handle/1884/24230/AdnilsonKawahibUFPR2010.pdf?sequence=1\&isAllowed=y .

Almeida Silva, A. (2015). Territorialidades, identidades e marcadores territoriais Kawahib da Terra Indígena UruEu-Wau-Wau em Rondônia. Jundiaí: Paco Editorial.

Araújo, J.S. (2018). Geografia do crime: Espacialização de homicídios e roubos ocorridos no município de Rio Branco como instrumento analítico de prevenção da criminalidade. (Dissertação de Mestrado em Geografia). Universidade Federal de Rondônia, UNIR, Porto Velho, RO, Brasil. Recuperado de http:/ /www.posgeografia.unir.br/ uploads/99999999/dissertacoes/MESTRADO/TURMA\%202016\%20MESTRADO/DISSERTACAO_\%20 JAQUELINE\%20SOUSA.pdf

Berstein, S. (1998). A cultura política. In J.P. Rioux, \& J.F. Sirinelli. Para uma história cultural. (pp.349-364). Lisboa: Estampa.

Bernal, R.J. (2009). Índios Urbanos: processo de reconstrução das identidades étnicas indígenas em Manaus. Manaus: Ed. UFAM. 
Bonnemaison, J. (1981). Voyage autour du territoire. L'Espace Geógraphique, 4: 249-262. Recuperado de https://www.persee.fr/doc/spgeo_0046-2497_1981_num_10_4_3673.

Bonnemaison, J., \& Cambrèzy, L. (1996) Le lien territorial: entre frontières et Identités. In J. Bonnemaison, L. Cambrèzy, \& B. Laurence. Territoire, Lien ou Frontière: Identités, Conflits Ethniques, Enjeux et Recompositions Territoriales. (pp. 7-18). Paris: L'Harmattan. (Géographies et Cultures, 20).

Brandão, C.R (1981). Pesquisa participante. São Paulo: Brasiliense.

Comissão Pró-Índio do Acre (s.d.). Parceiros e apoios. Rio Branco: CPI-AC. Recuperado de http://cpiacre. org.br/cpi-acre/parceiros-e-apoios/

Comissão Pró-Índio do Acre (2016). Povos e Terras Indígenas do Acre. Rio Branco: SEGEO/CPI-Acre. Recuperado de http:/ / cpiacre.org.br/ povos-e-terras-indigenas.

Comissão Pró-Índio do Acre (2020). Povos e Terras Indígenas do Acre. Recuperado de http:/ / cpiacre.org.br/ terras-indigenas-no-acre/

Conselho Indigenista Missionário. Conselho Regional Amazônia Ocidental (2012). Indígenas em espaço urbano no Acre. Rio Branco.

CPT Nacional (2020). Massacres no Campo: Primeiros dias de 2020 já registram ataques contra indígenas $e$ quilombolas. Recuperado de https://www.cptnacional.org.br/publicacoes/noticias/conflitos-nocampo/5055-primeiros-dias-de-2020-ja-registram-ataques-contra-indigenas-e-quilombolas.

Dardel, E. (2011) [1952]. O Homem e a Terra: natureza da realidade geográfica. São Paulo: Perspectiva.

Faria, I.F. (2003). Território e territorialidades indígenas do Alto Rio Negro. Manaus: Ed. UFAM.

Haesbaert, R. (2004). O mito da desterritorialização: do "fim dos territórios" à multiterritorialidade. Rio de Janeiro: Bertrand Brasil. $3 \mathrm{v}$.

Manchinery, A.S.S. (2014). Territorialidades do povo Manchineri. (Monografia de Conclusão de Curso em Geografia). Universidade Federal do Acre, UFAC, Rio Branco, AC, Brasil.

Oliveira, L. (2016). De rio em rio, meus olhares se encantam com a magia das águas. Revista Hipótese, 2(4):90-119. Recuperado de https://drive.google.com/file/d/0B4VVtZy9vhzvMjV1b3NTOVRRVFU/ view. Sobreiro Filho, J. (2013). O movimento em pedaços e os pedaços em movimentos: da ocupação do Pontal do Paranapanema à dissensão nos movimentos socioterritoriais camponeses. (Dissertação de Mestrado em Geografia). Universidade Estadual Paulista, UNESP, Presidente Prudente, SP, Brasil. Recuperado de https://repositorio.unesp.br/bitstream/handle/11449/96681/sobreirofilho_j_me_prud.pdf?sequence=1.

Spivak, G.C. (2010). Pode o subalterno falar? Belo Horizonte: Ed. UFMG.

\section{Entrevistas:}

E.S.S.M. - Rio Branco, Acre/2017

J.S.S.M. - Rio Branco, Acre/2018

V.O. - Rio Branco: Centro de Formação Povos da Floresta (CPI/AC)/2014.

Data de submissão: 08/maio/2020

Data de aceite: $17 /$ set. $/ 2020$ 